\title{
ОСОБЛИВОСТІ СУФІКСАЛЬНОГО СЛОВОТВОРЕННЯ НАЗВ РИБ В УКРАЇНСЬКИХ ГОВІРКАХ
}

Міняйло Р. В. Особливості суфіксального словотворення назв риб в українських говірках.

У статті досліджено продуктивні словотвірні моделі, що об'єднують назви риб у говірках української мови. Визначено їхні ареали, семантичне навантаження словотворчих афіксів, значеннєві відтінки, синонімічні зв'язки й конкурентні відношення.

Ключові слова: словотвірна модель, суфікс, назви риб, семантика. говорах.

Меняйло Р. В. Особенности суффиксального словообразования названий рыб в украинских

В статье исследуются продуктивные словообразовательные модели, которые объединяют названия рыб в говорах украинского языка. Определены их ареалы, семантическая нагрузка словообразовательных аффиксов, оттенки значений, синонимические связи и конкурентные отношения.

Ключевые слова: словообразовательная модель, суффикс, названия рыб, семантика.

Minyailo R. V. Peculiarities of suffix wordbuilding of the names of the fishes in Ukrainian dialects.

The author studies productive wordbuilding models, which unite the names of the fishes in Ukrainian dialects. The wordbuilding affixes semantics, their shades of meaning, synonimic and opposite relations their areas are studied.

Key words: wordbuilding model, suffix, fishes names, semantics.

В українських назвах риб деякі суфікси утворюють широкий ареал, бо, як зазначають дослідники, $є$ словотвірні типи, які характерні для всіх східнослов'янських мов, але зрідка відомі й у західно- та південнослов'янських мовах. Це зокрема агентивні назви з суфіксом для чол. p. -yн: напр., бігун [2, с. 109]. А оскільки процес номінування будь-якої живої істоти багато в чому схожий, можна провести паралелі між назвами людей і назвами риб, пор. сх.под. $\partial e^{u} p y^{\prime}$ 'йорж, Acerina cernua L.' [Тищ, с. 96], пд.-сх.полт. деру́н 'тс.' [Сиз, с. 26], полт. деру́н (дергу́н) 'тс.' [Ващ, с. 29], рівн. деру́н 'окунь' [Свт, с. 59], одес. де руин 'тс.' [Моск, с. 30], від де́рти (риба може обідрати руки); бук. жеру́н, жиру́н 'білизна, жерех' [Гуйв, с. 112] від же́рти (риба є надзвичайно зажерливою); одес. n’iскýн ‘бичок, що водиться на піщаному дні Дністровського лиману' [Моск, с. 58] 
від пісо́к; в'юн 'риба з видовженим тілом, Misgurnus fossilis' 3 фонетичними варіантами вою́н, ою́н від ви́ти 'скручувати' [ЕСУМ, I, c. 383] тощо. Цю словотвірну модель можна доповнити й іншими прикладами: рівн. ширху́н 'окунь' [Свт, с. 132], рівн. піску́н 'в'юн' [Свт, с. 99], сх.сл. писку́н 'тс.' [СУСГ, 160]. Помітним є те, що назви із затемненою внутрішньою формою, як, наприклад, усталений іхтіонім же́рех 'білизна, Aspius rapax', який загальноприйнятої етимології не має (його пов’язують із жерти, що підтверджено зажерливістю цієї риби; уважають спорідненим 3 шв. gärs 'йорж', норв. gjørs 'тс.', можливо, також 3 дінд. jhasáh < *jharsáh 'велика рибина') [ЕСУМ, II, с. 194], народна етимологія «підганяє» під звичну й семантично прозору словотвірну модель - жир-ун. Зважаючи на неї, можна підкріпити висновки українських етимологів, що поширена в загальнослов'янському ареалі лексема окунь, очевидно, також утворена за допомогою суфікса -унь від слова око (від псл. оko $\rightarrow$ okunь), бо під час виймання окуневих з великої глибини «в них випинаються очі від тиску газу в плавальному міхурі» [ЕСУМ, IV, с. 177]. У сучасній українській мові дослідники відзначають слабку продуктивність моделі «дієслівна основа + -ун», проте віддієслівні іменники 3 формантом -ун демонструють широкий діапазон часткових суб'єктних значень, зокрема назви тварин за характерною процесовою ознакою: ивіркун, гавкун, скакун, сисун, плазун та ін. [3, с. 214-215]. Можна констатувати, що формант -ун має певну продуктивність у говірках української мови, бо він утворює назви риб не лише від дієслівних, а й іменникових та прикметникових основ.

Як зазначили автори «Історичної граматики української мови», східнослов'янський і частково західно- й південнослов'янський ареал утворюють також атрибутивні назви осіб, понять і предметів на -ень та -ак [2, с. 109]. О. Царук у своїй відомій монографії, проаналізувавши активні суфіксальні утворення, типові переважно для антської мовної підгрупи, дійшов висновку про «українсько-західнослов'янську єдність» функціювання форманта *-akъ [7, с. 231].

У загальноукраїнському континуумі словотвірна модель із суфіксом -ень має лише поодинокі відповідники: бойк. ко́ўбён', ко́бен' 'бичок, Gobius fluviatilis' [Ониш, I, с. 363]; сх.под. го́лови $\mu^{e}$ ', голове́н', гла́ве н' 'прісноводна риба родини коропових із товстою головою і широким лобом, Leuciscus cephalus L.' [Тищ, с. 95], сх.пол. галавень 'тс.' [Дейн, 173] цн.сл. голове́н' 'тс.' [КА], сх.сл. го́лове́н' 'тс.' [КА], сх.сл. де́бен' 'окунь, Perca fluviatilis L.' [KA].

Натомість суфікс - ак в українських говірках досить продуктивний: зх.пол. шчира́к 'дрібна річкова риба родини коропових, піскар, Gobio gobio L.' [Арк, II, с. 281], зх.пол. шчупа́к 'самець щуки, Esox Lucius L.' [Арк, II, с. 282], рівн. щупа́к 'тс.' [Свт, с. 136], сх.под. шчупа́к 'молода щука' [Тищ, с. 97], ср.ндпр. росля́к 'великий підуст’ [Тар, с. 59], 
одес. аўстр’ійáк 'світлого кольору бичок, що водиться на дні Дністровського лиману' [Моск, с. 13], одес. мурза́к 'порода бичків, яка водиться на дні лиману в мулі' [Моск, с. 51], нж.ндстр. кланца́к 'порода бичків, водиться на дні лиману в болоті; тулуб має темне забарвлення, голова приплюснута' [Берл, с. 46], одес.горча́к 'неїстівна дрібна рибка-колючка' [Моск, с. 25], цн.сл. гірча́к 'порода риби' [Грінч, I, с. 286] i т. ін. Назву гірчак (прісноводна риба родини коропових, Rhodeus amarus, Rhodeus sericeus amarus (Bloch.) етимологи пов'язують зі словом гірки́й [ЕСУМ, I, с. 516], тобто м'ясо цієї риби гірке на смак. Суфікс -ак є продуктивним не лише для творення видових назв риб, але й для творення інших назв, пов'язаних зі специфічними, власне рибальськими характеристиками об'єкта промислу, напр.: нж.ндпр. свіжа́к 'щойно вловлена, свіжа риба' [Чаб, IV, с. 60], нж.ндпр. спичак 'риба-самець під час нересту' [Чаб, IV, с. 92], ср.ндпр. с[и]пича́к 'риба-самець' [Tар, с. 59], ср.ндпр. молочня́к 'тс.' [Тар, с. 59], лемк. млічак 'тс.' [Пирт, с. 176], бук. слиза́к 'різновид риби із слизистою поверхнею' [Гуйв, с. 500], сх.сл. сопл'а́к 'йорж’ [Сват, с. 87], сх.пол. сопляк 'тс.' [Дейн, с. 173], ср.ндпр. слюзя́к, сопля́к 'тс.' [Тар, с. 60], ср.ндпр. біля́к 'біологічний різновид лящя' [Тар, с. 59], сх.под.мор'áк 'окунь' [Тищ, с. 96], ср.ндпр. глистя́к 'лящ вагою до півкілограма' [Tap, с. 58], сх.сл. шлапа́к ‘велика риба: приблизно від 2 кг і більше' [КА].

Отже, на противагу віддієслівним іменникам чоловічого роду словотвірної категорії особи, де словотвірні типи з суфіксом -ак (-як) є малопродуктивними як у сучасній українській мові, так i взагалі в слов'янських мовах [5, с. 421], творення назв риб за допомогою цього афікса від іменникових і прикметникових основ є продуктивним.

Як стверджують авторитетні українські історики мови, паралельні суфікси, серед них і засвоєні з інших мов, відомі вже мові давньоруській (за Ю. Шевельовим - протоукраїнській), а в давньоукраїнській мові таких паралельних суфіксів далеко більше [2, с. 112]. Учені наводять приклади, зокрема писець - писарь, винникъ - винарь, коваль - ковачь, камыкькамень і т. ін. [Там само]. Схожі паралелі ми простежуємо й у досліджуваних лексемах. Назви риби бичка: гуц. бабе́u [Закр, с. 19]нж.ндпр. ба́бик [Чаб, I, с. 53]. Назви риби головня: лемк. гвыч [Пирт, с. 68], гуц. голо́ва́ч [Закр, с. 47], пор. староукр. главачъ, главичь [СлУМ, VI, с. 213] - сх.под. го́лови 'н', голове́н', голова́н', гла́ве "н' [Тищ, с. 95], сх.пол. галавень [Дейн, 173], цн.сл. голове́н' [КА], сх.сл. го́ло́ве ' $^{\prime}$, го́лове $e^{u}$ ' [KA], пор. також закарп. гоิлоิві́л' 'риба Salmo hucho' [Саб, с. 50]. Назви риби окуня: бук. ко́стриж, ко́строж, ко́струж [Гуйв, с. 226]сх.сл. костре́щзь [СУСГ, 104] тощо.

Суфікс -ач є продуктивним для утворювання назв риб у всіх говірках української мови (при цьому цей словотворчий афікс нерідко надає словам певної стилістичної зниженості, відтінку просторіччя, фамільярності), пор. 
сх.под. шмарка́ч 'йорж, Acerina cernua L.' [Тищ, с. 96], пол. слюмка́ч 'йорж, Nemachilus barbatula L.' [Лис, с. 198], сх.сл. с'урка́ч' 'окунь, Perca fluviatilis L.' [KA], сх.под. шчукáч, шчуnáч 'молода щука вагою 600-700 г' [Тищ, с. 97], ср.ндпр. плеска́ч 'молодий клепець' [Тар, с. 59] і т. ін.

Досліджуючи суфіксальні утворення в сучасній українській мові, учені засвідчують «конкуренцію суфіксів - ар і -ник», відзначаючи, що похідники із суфіксом -ар утворюють тоді, «коли через певні причини суфікс -ник не може функціонувати: збіг кількох приголосних, що не властиве структурі української мови, або інше семантичне навантаження суфікса» $[4$, с. 129]. Аналізуючи сучасну мову української преси, Т. Коць з'ясувала також, що відіменні похідники з суфіксом -ник «мають яскраво виражений розмовний характер» [Там само]. Притаманне це й говірковим назвам риб, які утворють за допомогою цього суфікса, напр.: пол. гуло́вник 'головень' [Лис, с. 61], цн.сл. голо́ўник 'тс.' [КА], сх.сл. голоўни́к 'тс.' [Сікор, с. 40], сх.ст. голо́ўник 'тс.' [КА], ср.ндпр. моло́шник 'риба-самець' [Tap, с. 59]. Таке функційне навантаження мають i синонімічні суфікси -ик/-чик та їхні фонетичні варіанти: бойк. кленик 'головень, Squalius cephalus L.' [Ониш, I, с. 358]; бук. ле́шик 'лящ’ [Гуйв, с. 257], нж.ндстр. ля́щик 'риба, зменш. від лящ' [Берл, с. 53], ср.ндпр. кі́злик, ко́злик 'лящ вагою до півкілограма' [Тар, с. 58], нж.ндпр. ки́злик 'маленький лящ' [Чаб, II, с. 165], ко́злик 'малий, молодий лящ' [Ліп, с. 47], сх.сл. ч’аба́ч'ік 'зменш.-пестл. до ч'аба́к, лящ, Abramis brama L.' [KA]; нж.ндстр. коро́nчик 'зменш. від коро́п, молоденький, маленький короп' і шара́нчик 'зменш. від шаран, короп' [Берл, с. 48, с. 80]; зх.пол. зе́лик 'молодий щупак' [Арк, I, c. 188], ср.ндпр. щуге́лик 'молода щука (вагою 600-700 г)' [Тар, с. 58]; ср.ндпр. чо́пик 'судак до нересту' [Тар, с. 58], нж.ндпр. чо́пик 'невеликий судак’ [Чаб, IV, с. 219], одес. чо́nик 'судачок' (зменшено-фамільярне) [Моск, с. 76]; бук. ко́вблик 'зменш. до ко́вбель (пічкур)' [Гуйв, с. 214], зх.пол. ко́блик 'дрібна річкова риба; піскар' [Арк, I, с. 231], рівн. ко́блик 'тс.' [Євт, с. 72], одес. ко́блик 'тс.' [Моск, с. 41]; рівн. оселе́дчик 'дрібна прісноводна риба родини коропових' [Свт, с. 93], нж.ндпр. саладро́нчик 'зменш.-пестл. до саладро́н (риба-верховодка)' [Чаб, IV, с. 53]; рівн. ко́стрик і сопли́вчик 'йорж, дрібна прісноводна риба 3 колючими плавцями' [Свт, с. 75, с. 117], пол. наса́рик ‘зменш.-пестл. до наса́р (вид йоржа)' [Лис, с. 134], сх.ст. йо́ршик '(зменш.-пестл.) дрібна прісноводна риба родини окуневих із колючими плавцями' [ОмКл, с. 40]; нж.ндстр. со́мик 'зменш. від сом, молоденький, маленький сомик' [Берл, с. 72] і сх.ст. с'о́м'ік 'найдрібніша за розміром хижа риба ряду окунеподібних зеленувато-сірого кольору з темними смугами по боках і світлим черевцем, що живе в прісній і морській воді' [ОмКл, с. 99]; нж.ндстр. кара́сік 'Зменш. від карась' [Берл, с. 45]; одес. пука́сик 'манюсінька рибка' [Моск, с. 62]; пд.-сх.полт. ц̧а́рик 'маленька річкова 
рибка, схожа на піскаря чи на бубиря, сіренького кольору, яку використовують як живця' [Сиз, с. 91].

Суфікси -ник, -ик, -чик продуктивні в усіх трьох наріччях української мови. Для окремих назв помітна тенденція десемантизації демінутивного значення: напр., у говірках південно-західного наріччя - кленик, лещик, південно-східного i північного- головник, хоч це явище не набуло системного характеру.

Що стосується суфікса -ець, то його багатофункційність учені простежили ще в староукраїнській мові XIV-XV ст.: «-ець у зменшених іменниках і -ець як формант, що субстантивує прикметникову основу» [Гум, с. 86]. За допомогою суфікса -ец/-ецьь утворюють як видові назви риб, так і їхні відповідники з конотацією пестливості чи фамільярності, а також найменування риб за ознакою статі: нж.ндстр. сине́usь 'риба' [Берл, с. 71], сх.под. коропе́u', корупе́u' 'молодий короп' [Тищ, с. 97], одес. шаране́u' 'зменш.-фам. до шара́н (короп)' [Моск, с. 77], бук. рибе́u, ребе́u 'лящ' [Гуйв, с. 454], нж.ндпр. клипе́usь 'риба з родини коропових' [Чаб, II, с. 177], сх.ст. клипе́u’' 'молодий лящ' [ОмКл, с. 45], одес. клепе́ц̧ь 'назва риби, відомої під назвою «глазач»' [Моск, с. 41], нж.ндпр. бобире́uьь, бубире́us 'йорж, Acerina cernua L.' [Чаб, I, с. 92, с. 108], сх.под. окуне́ц', дируне́ц' 'окунь невеликого розміру' [Тищ, с. 97], нж.ндпр. оюне́и̧ь 'зменш.-пестл. до оюн (в’юн)' [Чаб, III, с. 69], сх.сл. селеде́uь 'в’юн, Misgurnus Fossilis L.' [КА], сх.под. шчупал'е́u' 'молода щука' [Тищ, с. 97], ср.ндпр. гоне́иь 'риба-самець' [Тар, с. 59]. Назва клепе́ц̧ь (білозірка, Abramis sapa Pall.), як припускають етимологи, може мати зв’язок із клі́namu з огляду на великі очі білозірки, а також із клепа́ти 'бити; сплющувати', зумовлений сильно сплющеною з боків, плоскою формою тіла цієї риби [ЕСУМ, II, с. 459].

3 наведених прикладів також можна виснувати, що суфікс -eu/-eu̧, який переважно надає семантичного відтінку зменшеності, більш продуктивний у говірках південно-східного наріччя.

У синонімічні відношення найчастіше вступають назви риб 3 суфіксами -чик і -ецьь, пор.: коропчик-коропец̧ь, щаранчик- шаранець тощо. Григір Тютюнник у межах одного оповідання подає такі само два синоніми з говірок Полтавщини: дерунчик і дерунецзь [6, с. 45, с. 48].

Суфікс -ок вносить значеннєвий відтінок зменшеності, утворюючи назви риб невеликого розміру або їх зменшено-пестливі назви: напр., нж.ндстр. бичо́к 'риба' [Берл, с. 29], сх.ст. бичо́к 'невелика головата морська риба' [ОмКл, с. 12], зх.пол. вкун'о́к 'невеликий окунь, Perca fluviatilis' [Арк, I, с. 66], пд.-сх.полт. линьо́к 'малий лин' [Сиз, с. 49], нж.ндстр. лино́к 'риба, зменш. від лин' [Берл, с. 52], зх.пол. лино́к 'прісноводна риба родини коропових з товстим слизьким тілом; Tinca tinca' [Арк, I, с. 284], рівн. кліно́к 'головень' [Свт, с. 72], одес. мин'о́к 'маленька рибка, подібна до пискаря' [Моск, с. 51], ср.ндпр. підре́йок, nідри́йок 'молодий короп' [Тар, с. 59], нж.ндпр. пидре́йок 'однорічний 
коропець', пі́дрийок 'тс.' [Чаб, III, с. 109], пд.-сх.полт. підри́йок 'тс.' [Сиз, c. 69], ср.ндпр. цигано́к 'біологічний різновид лящя' [Tap, с. 59], нж.ндпр. чабачо́к 'малий, молодий лящ' [Ліп, с. 47], сх.ст. чабачо́к 'молодий лящ' [ОмКл, с. 110], сх.сл. ч'абач'óк 'тс.' [КА] і 'зменш.-пестл. до чабак' [Сікор, с. 212], нж.ндстр. судачо́к 'Зменш. від суда́к, молодий судак' [Берл, с. 74], пор. староукр. жеречокъ 'малий жерех, жерешок' [СлУМ, IX, с. 145].

Л. Гумецька, дослідивши українську актову мову XIV-XV ст., дійшла висновку, що суфікси -окъ, -икъ були синонімічними й утворювали назви зменшених предметів. Проте в сучасній українській мові, як помітили діалектологи, порівняно $з$ синонімічними -ик, -ець суфікс -ок менш експресивний. В українських говірках є багато десемантизованих демінутивів цього словотвірного типу. Зокрема для степового говору української мови, як свідчить М. Бухтій, характерним є більш-менш тривале паралельне вживання таких десемантизованих демінутивів, які виникли внаслідок «нейтралізації демінутивного значення субстантивів 3 суфіксом -ок під впливом словотвірних типів з цим же суфіксом, і слів, що їх мотивують, у тому самому значенні», напр.: по́плав - поплаво́к 'поплавок на верхах невода', каюк - каючок 'невеликий рибальський човен довжиною до 4 м, підйомністю до тонни' [1, с. 127]. Переконливим $є$ приклад варіантної пари по́плав - поплаво́к, компоненти якої утворено від однієї і тієї ж (дієслівної) основи, але перший - безафіксним способом, а другий - суфіксальним: по́плав $\longleftarrow$ поплавляти(ь) $\rightarrow$ поплаво́к [Там само].

Суфікс -к- має ширший спектр семантичних відтінків. До цієї словотвірної моделі належать: а) назви риб невеликого розміру: бук. ба́бка 'вид риби, бичок' [Гуйв, с. 20], ндстр. ба́бка 'тс.' [Шило, с. 94], одес. бабки́ 'бички (риба)' [Моск, с. 14]; б) назви на позначення молодої риби: зх.пол. кро́чка 'молодий короп, Cuprinus carpio' [Арк, I, с. 257], зх.пол. шчу́чка 'невелика щука, Esox Lucius L.' [Арк, II, с. 283]; в) зменшені назви риб: нж.ндстр. ласки́рка 'риба, зменш. від ласки́р' [Берл, c. 51], нж.ндстр. тара́нька 'зменш. від тарань, риба' [Берл, с. 75], г) назви риб звичайного й навіть великого розміру: бойк. ба́бка 'головень' [Ониш, I, с. 37], зх.пол. черво́нка 'краснопірка, Scardinius erythrophthalmus' [Арк, II, с. 248], нж.ндпр. коби́лка 'тс.' [Ліп, с. 57], сх.под. си́н'ка 'верховодка, Alburnus alburnus L.' [Тищ, с. 94]. Стосовно останньої підгрупи назв 3 нейтральною семантикою справедливими $\epsilon$ висновки М. Бухтія, що типовим явищем субстантивного словотворення $\epsilon$ занепад семантики зменшеності деяких суфіксів, унаслідок чого «утворені деривати сприймаються як розмовні варіанти мотивуючих слів 3 ідентичним лексичним значенням» [1, с. 126]. Аналізуючи суфіксальну десемантизацію іменників у степових говірках української мови, він наводить приклади варіантності структурного типу ø : -к(a): ля́мa - ля́мка 'невеликий відрізок каната, товстої мотузки, сітяного полотна, яким, 
прикріпившись до тягової колоди, тягнуть невід до берега', кодо́ла кодо́лка 'верхній і нижній канатики (мотузки), до яких прив’язане полотно невода', стіна́ - стінка 'риболовна сіть, якою перегороджують упоперек усю річку', пла́ха - пла́шка 'вузький довгий мішок у неводі' і т. ін. Дослідник також виділив різновиди варіантних пар, зокрема: 1) іменники 3 абсолютною тотожністю семантики: напр., сандо́ля - сандо́лька 'риболовне знаряддя у вигляді вил (найчастіше 3 трьома, рідше 3 двома, п’ятьма зубцями з гострими зазубринами на кінці для утримування настромленої риби), яким наколюють рибу, кидаючи його з берега або човна', чорну́ха чорну́шка 'вид риби'; 2) іменники виступають варіантами в одних значеннях, розходяться в інших: напр., ялина - ялинка 'довга жердина із сталевим наконечником, якою відштовхуються з човнів на Дніпрі, пливучи проти течії' [Там само, с. 126-127].

Семантично розмаїтими є й синонімічні суфікси -ук, -чук, які надають назвам риб: а) виразної семантики приналежності до чоловічого роду: зх.пол. волос'ýк 'щупак' [Арк, I, с. 71], сх.пол. меню́к 'вид озерної, ставкової риби' [Зел, с. 24], нж.ндпр. піскарчу́к 'піскар' [Чаб, III, с. 124]; б) семантичних відтінків зменшеності й просторіччя: бук. кленчу́к 'зм. до клень (головень)' [Гуйв, с. 208], сх.под. клинчу́к 'тс.' [Тищ, с. 95], сх.под. л'ашчу́к 'молодий лящ вагою до 1 кг' [Тищ, с. 97], ср.ндпр. козлю́к ‘лящ вагою до півкілограма' [Тар, с. 58], сх.под. коропчу́к 'молодий короп' [Тищ, с. 97], ср.ндпр. в 'язю́к 'молодий в'язь (вагою до 500 г)' [Тар, с. 58].

Отже, аналіз утворених суфіксальним способом назв риб у говірках української мови дозволяє дійти висновків: назви утворюють від дієслівних, іменникових і прикметникових основ; найбільш продуктивними є похідники від іменникових основ; суфікси -ник, -ик, -чик здебільшого надають назвам конотації зменшеності й пестливості, суфікси -ак, -ач- відтінку просторіччя, фамільярності; семантично розмаїтими є суфікси -aк, -ец/-ець, -ик, -чик, -ук, -чук, за допомогою яких утворюють як видові назви риб, так і їхні відповідники 3 конотацією пестливості чи фамільярності, а також найменування риб за ознакою статі (риба-самець); найчастіше вступають у синонімічні відношення назви риб з суфіксами -чик і -ець; найширший спектр семантичних відтінків має суфікс-к-; для похідників із суфіксом -ок характерна десемантизація демінутивного значення.

\section{Умовні скорочення}

Бойк. - бойківське, бук. - буковинське, гуц. - гуцульське, закарп. - закарпатське, зх.пол. західнополіське, КА - картотека автора, лемк. - лемківське, ндстр. - наддністрянське, нж.ндпр. нижньонаддніпрянське, одес. - говірки Одещини, пд.-сх.полт. - південно-східнополтавське, пн.-сх.полт. - північно-східнополтавське, пол. - поліське, полт. - полтавське, рівн. - говірки Рівненщини, ср.ндпр. - середньонаддніпрянське, ср.пол. - середньополіське, староукр. - українська мова ранньосередньоукраїнського й середньоукраїнського періодів (за Ю. Шевельовим), сх.под. східноподільське, сх.поліс. - східнополіське, сх.сл. - східнослобожанське, сх.ст. - східностепове, цн.сл. центральнослобожанське.

Умовні скорочення використаних джерел

Арк - Аркушин Г. Л. Словник західнополіських говірок : у 2-х т. / Г. Л. Аркушин. - Луцьк : Вежа, 2000. - T. 1-2. 
Берл- Берлізов А. А. Лексика рибальства українських говорів Нижнього Подністров’я / А. А. Берлізов // Наукові записки Чернігівського педагогічного інституту. - Чернігів : ЧДПІ, 1959. T. IV. - Вип. 4. -82 c.

Ващ - Ващенко В. С. Словник полтавських говорів / В. С. Ващенко. - Х. : Вид-во Харк. ун-ту, 1960. - 107 c.

Грінч - Словарь української мови. Зібрала редакція журнала «Кіевская Старина» : у 4-х т. / [упоряд. 3 дод. власн. матеріалу Борис Грінченко]. - Надрук. $з$ вид. 1907-1909 рр. фотомеханіч. способом. - К. : Наукова думка, 1996-1997. - Т. 1-4.

Гуйв - Словник буковинських говірок / [за заг. ред. Н. В. Гуйванюк]. - Чернівці : Рута, 2005. - 688 с.

Дейн - Дейниченко Н. Ареальне членування східнополіського говору (за матеріалами зоологічної лексики) // Український діалектологічний збірник : Кн. 3 / Відп. ред. П. Ю. Гриценко. - К. : Довіра, 1997. - С. 172-176.

ЕСУМ - Етимологічний словник української мови : у 7-и т. / [гол. ред. О. С. Мельничук]. - К. : Наук. думка, 1982-2006. - Т. 1-5.

Свт - Свтушок О. М. Вивчення лексики говірок Рівненщини / О. М. Свтушок. - Рівне, 1997. - 164 с.

Закр - Гуцульські говірки : короткий словник / [відп. ред. Я. Закревська].- Львів : Інститут українознавства ім. І. Крип'якевича НАН України, 1997. - 232 с.

Зел - Зеленько А. С. Словник східнополіського говору / А. С. Зеленько, І. В. Сенчук, Ф. Я. Середа // Методичні вказівки 3 діалектології української мови (та матеріали до словника східнополіського говору). - Луганськ : ЛДПІ, 1990. - С. 5-40.

Корз - Корзонюк М. М. Матеріали до словника західноволинських говірок / М. М. Корзонюк // Українська діалектна лексика : [зб. наук. праць / редкол. : І. Г. Матвіяс та ін.]. - К. : Наук. думка, 1987. C. 62-267.

Лис - Лисенко П. С. Словник поліських говорів / П. С. Лисенко. - К. : Наук. думка, 1974. - 260 с.

Лисич - Лисиченко Л. А. Особливості говірок східних районів (Куп'янського і Дворічанського) Харківської області : дис. ... канд. філол. наук / М-во вищ. освіти СРСР. Харк. держ. ун-т ім. О. М. Горького. - Х., 1954. - 188 с.

Ліп - Ліпкевич І. Г. Рибальська лексика в українських говірках Нижньої Наддніпрянщини : дис. ... канд. філол. наук. - Запоріжжя, 1993. - 246 с.

Моск - Москаленко А. А. Словник діалектизмів українських говірок Одеської області / А. А. Москаленко. - Одеса : ОДПІ ім. К. Д. Ушинського, 1958. - 78 с.

ОмКл - Омельченко 3. Л. Матеріали до словника східностепових українських говірок / 3. Л. Омельченко, Н. Б. Клименко. - Донецьк : Вид-во ДонНУ, 2006. - 114 с.

Ониш - Онишкевич М. Й. Словник бойківських говірок / М. Й. Онишкевич. - К. : Наук. думка, 1984. - Ч. I-II.

Пирт - Пиртей П. С. Короткий словник лемківських говірок / П. С. Пиртей / [упоряд. й підгот. до друку С. Д. Турчин]. - Івано-Франківськ : Сіверсія МВ, 2004. - 364 с.

Саб- Сабадош I. В. Словник закарпатської говірки села Сокирниця Хустського району / I. В. Сабадош. - Ужгород : Ліра, 2008. - 480 с.

Сват - Сватівщина : Матеріали фольклорно-діалектологічних експедицій / [за ред.

3. С. Сікорської]. - Луганськ : Осіріс, 1998. - 136 с.

Сиз - Сизько А. Т. Словник діалектної лексики говірок сіл південно-східної Полтавщини / А. Т. Сизько. - Дніпропетровськ : ДДУ, 1990. - 100 с.

Сікор - Сікорська 3. С., Шевцова В. О., Шутова Л. І. Словник діалектної лексики Луганщини / [за ред. 3. С. Сікорської]. - К. : Шлях, 2002. - 224 с.

СлУМ - Словник української мови XVI - першої половини XVII ст. : у 28-и вип. / [відп. ред. Д. Гринчишин]. - Львів, 1998.

СУСГ- Словник українських східнослобожанських говірок / К. Глуховцева, В. Лєснова, I. Ніколаєнко, Т. Терновська, В. Ужченко. - Луганськ : Альма-матер, 2002. - 234 с.

Тар - Тарасенко Г. Д. Місце рибальської лексики Середньої Наддніпрянщини в словниковому складі української мови / Г. Д. Тарасенко // Діалектологічний бюлетень. - Вип. VIII. - К., 1961. C. 57-63.

Тищ - Тищенко Т. Номінація риб у говірках Східного Поділля / Т. Тищенко // Мовознавчий вісник : [зб. наук. праць] / МОН України. Черкаський нац. ун-т ім. Б. Хмельницького ; [відп. ред. Г. І. Мартинова]. - Черкаси : Видавець Чабаненко Ю. - 2010. - Вип. 10. - С. 94-101.

Чаб - Чабаненко В. А. Словник говірок Нижньої Наддніпрянщини / В. А. Чабаненко : у 4-х т. Запоріжжя, 1992. - Т. 1-4.

Шило - Шило Г. Наддністрянський регіональний словник / Г. Шило. - Львів : Інститут українознавства ім. І. Крип’якевича НАН України, 2008 (Серія «Діалектологічна скриня»). - 288 с. 


\section{Література}

1. Бухтій М. Суфіксальна десемантизація іменників у степових говірках української мови / М. Бухтій // Сучасні проблеми мовознавства та літературознавства : [зб. наук. праць]. - Вип. 4: Українське і слов'янське мовознавство (Міжнародна конференція на честь 80-річчя професора Йосипа Дзендзелівського). - Ужгород, 2001. - С. 126-129.

2. Історична граматика української мови : [навч. посібн.] / М. А. Жовтобрюх, О. Т. Волох, С. П. Самійленко, І. І. Слинько. - К. : Вища школа, 1980. - 319 с.

3. Колібаба Л. М. Асиметрія словотвірних співвідношень багатозначних дієслів та іменникових девербативів / Л. М. Колібаба. - К. : Інститут української мови НАН України, 2005. - 349 с.

4. Коць Т. А. Літературна норма у функціонально-стильовій і структурній парадигмі / Т. А. Коць. К. : Логос, 2010. - 303 с. - (Студії з українського мовознавства).

5. Панцьо С. Назви осіб у лемківському діалекті / С. Панцьо // Сучасні проблеми мовознавства та літературознавства: [зб. наук. праць]. - Вип. 4: Українське і слов'янське мовознавство (Міжнародна конференція на честь 80-річчя професора Йосипа Дзендзелівського). - Ужгород, 2001. - С. 419-422.

6. Тютюнник Г. М. Твори. Книга I: Оповідання / Григір Михайлович Тютюнник ; [упоряд. А. Шевченко; передм. О. Гончара]. - К. : Молодь, 1984. - 328 с.

7. Царук О. Українська мова серед інших слов'янських: етнологічні та граматичні параметри : [монографія] / Олександр Царук. - Дніпропетровськ : Наука і освіта, 1998. - 324 с. 